\title{
APLIKASI EKSTRAK BAWANG PUTIH (Alium sativum) UNTUK MEMPERPANJANG DAYA SIMPAN IKAN KEMBUNG SEGAR (Rastrelliger kanagurta)
}

\author{
Sumpeno Putro*), Dwiyitno*), Juan Fransisco Hidayat"), dan Maruli Pandjaitan**)
}

\begin{abstract}
ABSTRAK
Ikan memiliki karakteristik sebagai bahan pangan yang sangat mudah mengalami kemunduran mutu, terutama oleh aktivitas mikroorganisme pembusuk. Sementara itu bawang putih ( $A$. sativum) telah dikenal memiliki kandungan antimikroba sehingga berpotensi menghambat pertumbuhan bakteri pembusuk pada ikan. Tujuan dari penelitian ini adalah untuk melihat potensi ekstrak bawang putih sebagai antimikroba pada penanganan ikan kembung segar $(R$. kanagurta). Perlakuan yang digunakan adalah perendaman ikan segar dalam ekstrak bawang putih dengan konsentrasi $0,2,4$, dan $6 \%$ selama 15 menit. Hasil penelitian menunjukkan bahwa perendaman dalam ekstrak bawang putih dapat menghambat pertumbuhan bakteri, baik bakteri pembusuk maupun bakteri pembentuk histamin. Konsentrasi ekstrak bawang putih 2, 4, dan $6 \%$ dapat memperpanjang daya simpan ikan kembung segar pada suhu kamar 6 jam lebih lama dibandingkan dengan kontrol. Di samping itu, perlakuan perendaman ekstrak bawang putih dapat meningkatkan nilai organoleptik ikan. Sebaliknya, perendaman dalam ekstrak bawang putih tidak berpengaruh nyata terhadap kandungan air dan TVB ikan. Walaupun demikian, bawang putih memiliki potensi sebagai bahan pengawet alami untuk memperpanjang kesegaran ikan.
\end{abstract}

ABSTRACT: The use of garlic extract (Alium sativum) in the preservation of Indian mackerel (Rastrelliger kanagurta). By: Sumpeno Putro, Dwiyitno, Juan Fransisco Hidayat and Maruli Pandjaitan

Fish is a highly perishable product which undergoes rapid deterioration due to spoilage process caused mainly by spoilage microorganisms. Garlic extract (A. sativum) that possesses antimicrobial properties may hinder the growth of spoilage microorganisms, and therefore, potentially able to maintain fish freshness. The purpose of the present study is to investigate the effectiveness of garlic extract as an antimicrobial agent in fish preservation. The treatment included soaking of Indian mackerels (R. kanagurta) in 0, 2, 4 and 6\% of garlic extract for 15 minutes respectively. The results showed that the use of garlic extract inhibited the growth of either spoilage microorganisms or histamine forming bacteria of Indian mackerel. The soaking treatments of fish in 2, 4 and $6 \%$ of garlic extracts were able to prolong Indian mackerel shelf life at ambient temperature storage up to 6 hours in comparison to control. In addition, the soaking in garlic extract improved the organoleptic characteristics of the fish. In contrast, the use of garlic extract did not show significant effect on the moisture and TVB level. However, garlic extract showed good potency to be used as a natural preservative to maintain fish freshness.

KEYWORDS: Rastrelliger kanagurta, Alium sativum, fish preservation

\section{PENDAHULUAN}

Ikan dikenal sebagai bahan pangan yang sangat mudah rusak, lebih-lebih pada iklim tropis seperti di Indonesia. Kerusakan ikan terutama disebabkan oleh aktivitas mikroorganisme pembusuk yang secara alamiah merusak ikan segera setelah ikan mati. Di samping itu, reaksi enzimatis serta kimiawi juga turut berperan pada proses kemunduruan mutu ikan. Biasanya, kemunduran mutu ikan ditandai dengan hilangnya bau ikan segar yang berubah menjadi bau busuk, kerusakan fisik seperti perubahan pada tekstur, insang, permukaan kulit dan mata, maupun perubahan/penurunan kandungan nutrisinya (Desrosier, 1988).

Temperatur merupakan faktor eksternal yang berperan penting pada proses kemunduran mutu ikan. Hal ini karena bakteri-bakteri pembusuk berkembang lebih cepat pada suhu yang lebih tinggi. Selain faktor eksternal, faktor internal juga berperan pada proses kemunduran mutu ikan. Namun demikian, faktor internal lebih berkaitan dengan komposisi kimia ikan dan sulit dikendalikan dibandingkan dengan faktor eksternal yang berhubungan dengan kondisi

") Peneliti pada Balai Besar Riset Pengolahan Produk dan Bioteknologi Kelautan dan Perikanan, DKP

") Mahasiswa Swiss-German University

(m) Staf Pengajar pada Swiss-German University 
lingkungan maupun cara penanganan (Wibowo \& Yunizal, 1998).

Sampai saat ini, penanganan dengan suhu rendah (chilling) merupakan teknik penanganan ikan yang paling banyak digunakan. Es umumnya digunakan untuk mempertahankan kesegaran ikan selama penanganan maupun distribusi/transportasi. Pada suhu kamar $\left( \pm 25^{\circ} \mathrm{C}\right)$, ikan umumnya hanya bertahan antara 6-12 jam, sedangkan dengan perlakuan es dapat mempertahankan mutu ikan hingga 1-2 minggu. Pada suhu sekitar $0^{\circ} \mathrm{C}$, pertumbuhan bakteri-bakteri pembusuk maupun aktivitas enzim menjadi terhambat atau bahkan terhenti (Muchtadi, 1997). Sementara itu dengan pembekuan (freezing), mutu ikan dapat dipertahankan hingga satu bulan bahkan lebih dari satu tahun (Desrosier, 1988).

Mengingat Indonesia merupakan negara kepulauan, ketersediaan es dengan harga yang terjangkau sering menjadi kendala, terutama pada daerah-daerah terpencil yang jauh dari tempat produksi es. Hal ini tentu akan sangat berpengaruh terhadap mutu ikan yang dihasilkan. Akibatnya, praktek penanganan ilegal pun sering dilakukan untuk mempertahankan kesegaran ikan, misalnya dengan menggunakan formalin. Padahal, bahan-bahan alami seperti jahe (Zingiber officinale), kunyit (Curcuma sp.), picung (Pangium edule), hyssop (Hysoppus officinalis), brunella (Prunella vulgaris), dan rosemary (Rosmarinus officinalis) telah diketahui memiliki potensi untuk menghambat kemuduran mutu ikan selama penyimpanan (Andarwulan et al., 1999; Suharti, 2004; Lugasi et al., 2007).

Penelitian sebelumnya menunjukkan bahwa bawang putih berpotensi untuk mencegah pertumbuhan bakteri pembusuk, dan hasilnya lebih baik dibandingkan dengan jahe dan kunyit (Suharti, 2004). Pada penelitian lain, Haryati (2006) menggunakan ekstrak bawang putih untuk menghambat infestasi lalat pada pengolahan jambal roti. Pada penelitian ini, ekstrak bawang putih (Alium sativum) digunakan sebagai bahan untuk menghambat pertumbuhan bakteri dan memperpanjang daya simpan ikan kembung segar (Rastrelliger kanagurta).

\section{BAHAN DAN METODE}

\section{Pembuatan Ekstrak Bawang Putih}

Ekstrak bawang putih dibuat berdasarkan metode yang digunakan oleh Haryati (2006). Pada penelitian ini digunakan 4 perlakuan konsentrasi ekstrak bawang putih, yaitu $0,2,4$, dan $6 \%$. Untuk mendapatkan ekstrak bawang putih dengan konsentrasi $2 \%$, sebanyak $200 \mathrm{~g}$ bawang putih yang telah dikupas diblender dalam 10 liter air. Larutan bawang putih didiamkan selama 15 menit, kemudian disaring untuk memisahkan dari ampasnya.

\section{Preparasi Ikan, Perlakuan Perendaman dan Penyimpanan}

Ikan kembung yang digunakan pada penelitian ini diperoleh dari nelayan Muara Angke, Jakarta Utara. Ikan dengan ukuran 120-125 g/ekor dibawa ke laboratorium Balai Besar Riset Pengolahan Produk dan Bioteknologi Kelautan dan Perikanan, Jakarta dengan menggunakan peti berinsulasi (cool box) dan dipertahankan kesegarannya dengan es. Ikan kemudian disortasi berdasarkan ukurannya, dan dicuci.

Perendaman ikan dalam ekstrak bawang putih dilakukan pada suhu kamar selama 15 menit. Untuk $1 \mathrm{~kg}$ ikan digunakan 1 liter larutan ekstrak bawang putih hingga seluruh permukaan ikan terendam. Setelah perendaman, ikan selanjutnya ditiriskan, ditempatkan pada wadah berupa keranjang plastik dan disimpan pada suhu kamar. Pengamatan dilakukan setiap 6 jam sekali sampai mutu ikan ditolak oleh panelis.

Parameter yang diamati meliputi kadar air (metode oven; SNI 01-2354.2, 2006), kadar TVB-N (metode Conway; AOAC, 1990), total bakteri (Total Plate Count; SNI 01-2332.3, 2006), bakteri pembentuk histamin (Niven et al., 1981; Poerwadi \& Indriati, 1984). Nilai organoleptik yang diamati meliputi karakterisitik kenampakan, mata, insang dan lendir di permukaan kulit pada ikan mentah dengan metode demerit point. Karakter yang lebih baik ditunjukkan oleh skor organoleptik yang lebih rendah (Branch \& Vail, 1985). Untuk melihat pengaruh perlakuan perendaman dalam larutan ekstrak bawang putih terhadap karakteristik ikan setelah diolah, uji organoleptik terhadap parameter kenampakan, bau, rasa, dan tekstur dilakukan terhadap ikan yang dikukus berdasarkan nilai kesukaan panelis. Setiap perlakuan dilakukan pengulangan sebanyak 3 kali.

\section{HASIL DAN BAHASAN}

\section{Total Volatile Bases (TVB-N)}

TVB-N merupakan total senyawa yang mengandung nitrogen seperti monometil, dimetil, trimetil amin, dan amonia, yang terbentuk selama proses kemunduran mutu ikan (Haaland \& Njaa, 1989). Kandungan TVB akan semakin tinggi seiring dengan meningkatnya proses kerusakan/pembusukan ikan oleh bakteri pembusuk maupun reaksi enzimatis. Oleh karena itu, kandungan TVB sering digunakan 
sebagai parameter kebusukan ikan. Pada umumnya, ikan segar dikategorikan dalam kondisi prima apabila kandungan TVB-nya kurang dari $30 \mathrm{mgN} / 100 \mathrm{~g}$ (Connell, 1990). Sedangkan ikan dengan kandungan TVB hingga $40 \mathrm{mgN} / 100 \mathrm{~g}$ biasanya masih layak untuk dikonsumsi (Koizumi et al., 1985).

Kandungan TVB ikan sejak awal hingga akhir penyimpanan berkisar antara 15,99-169,35 mgN/100 $\mathrm{g}$ (Gambar 1). Pada penelitian ini pengaruh perlakuan perendaman dalam larutan ekstrak bawang putih dalam memperlambat sistesis TVB-N ikan kembung segar tidak berbeda nyata. Hal ini kemungkinan karena TVB-N tidak hanya dihasilkan dari proses pembusukan putih mampu menghambat pertumbuhan bakteri ikan kembung segar. Konsentrasi ekstrak bawang putih juga memberikan pengaruh yang berbeda dalam menghambat pertumbuhan bakteri pada ikan. Jumlah bakteri total lebih rendah pada perlakuan dengan konsentrasi ekstrak bawang putih yang lebih tinggi (Gambar 2). Perbedaan signifikan ditunjukkan pada penyimpanan jam ke-12, yaitu jumlah total bakteri pada ikan yang direndam dengan ekstrak bawang putih berkisar antara $7,1 \times 10^{6}-1,2 \times 10^{7} \mathrm{kol} / \mathrm{g}$ sedangkan kontrol $1,5 \times 10^{9} \mathrm{kol} / \mathrm{g}$. Hal ini kemungkinan disebabkan oleh kandungan alisin pada bawang putih yang bersifat antibakteri (Soetomo, 1987). Ekstrak

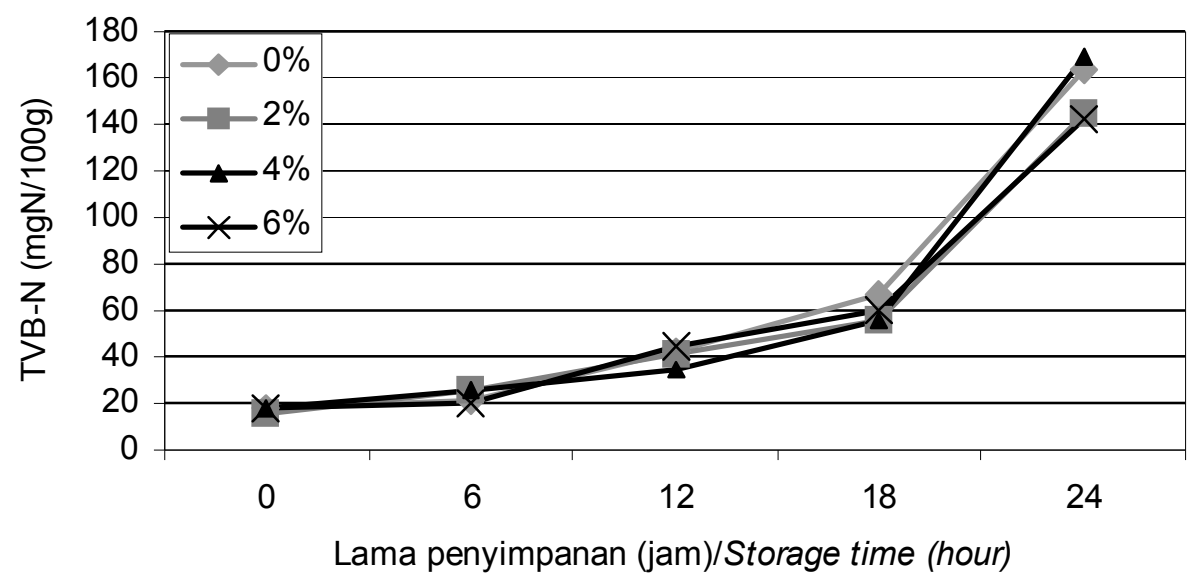

Gambar 1. Kandungan TVB-N ikan kembung segar hasil perlakuan perendaman ekstrak bawang putih selama penyimpanan pada suhu kamar.

Figure 1. TVB-N level of fresh Indian mackerel treated with garlic extract during storage at ambient temperature.

oleh mikroba, melainkan juga pengaruh kerusakan enzimatis (Zamir et al., 1999).

\section{Total Bakteri (Total Plate Count)}

Jumlah total bakteri merupakan salah satu parameter penting pada proses kemunduran mutu ikan. Hal ini karena kerusakan ikan utamanya disebabkan oleh aktivitas bakteri pembusuk. Akibat hilangnya sistem pertahanan alami ikan segera setelah mati, bakteri menjadi mudah masuk dan menyerang daging ikan melalui kulit, insang, dan saluran pencernaan (Connell, 1990; Gram \& Huss, 1996; Fraser \& Sumar, 1998). Pada penelitian ini, jumlah total bakteri berkisar antara 2,9 $\times 10^{3}$ (awal penyimpanan) hingga $1,6 \times 10^{10}$ (18 jam penyimpanan pada suhu kamar). Persyaratan angka lempeng total (ALT) untuk ikan segar adalah tidak lebih dari 5,0 x $10^{5} \mathrm{kol} / \mathrm{g}$ (SNI 01-2729.2, 2006).

Hasil analisis total bakteri menunjukkan bahwa perlakuan perendaman dalam larutan ekstrak bawang bawang putih telah diketahui dapat menghambat pertumbuhan bakteri gram positif maupun gram negatif. Penelitian yang dilakukan Suharti (2004) menunjukkan bahwa penggunaan $5 \%$ ekstrak bawang putih memiliki kemampuan menghambat pertumbuhan bakteri setara dengan tetrasiklin $100 \mathrm{~g} / \mathrm{mL}$.

Alicin menghambat pertumbuhan bakteri dengan cara mencegah sintesis DNA dan protein sel (Feldberg et al., 1988). Bakteri pembusuk yang berperan pada proses kemunduran mutu ikan antara lain Acinetobacter spp., Achromobacter spp., Pseudomonas spp., Moraxella spp., Aeromonas spp., Flavobacterium spp., Shewanella spp., serta beberapa jenis bakteri gram negatif lainnya. Sedangkan dari kelompok bakteri gram positif, Bacillus spp., Micrococcus spp., Clostridium spp., Corinebacterium spp., dan Lactobacillus spp. sering dijumpai pada ikan-ikan yang telah busuk (Buckle et al., 1987; Gram \& Huss, 1996). Faktor-faktor yang berperan dalam pertumbuhan bakteri-bakteri tersebut antara lain temperatur, $\mathrm{pH}$, oksigen, dan nutrien/substrat. 


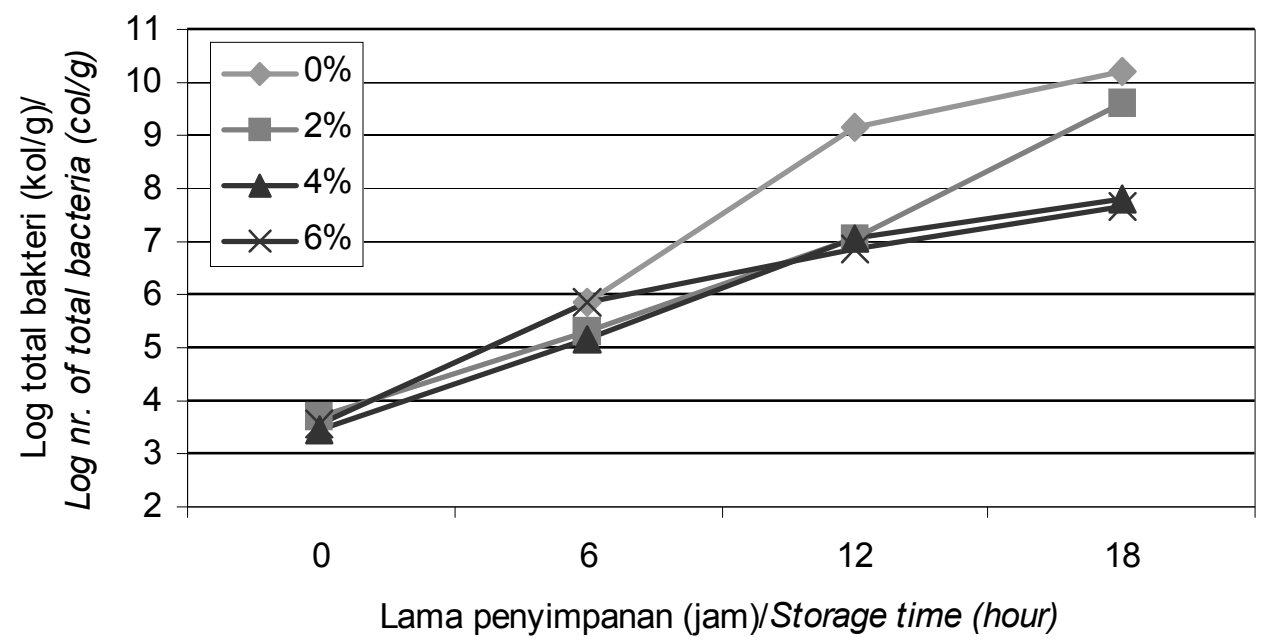

Gambar 2. Total bakteri ikan kembung segar hasil perlakuan perendaman ekstrak bawang putih selama penyimpanan pada suhu kamar

Figure 2. Total plate count of fresh Indian mackerel treated with garlic extract during storage at ambient temperature

\section{Bakteri Pembentuk Histamin}

Histamin adalah suatu senyawa amin yang dihasilkan oleh reaksi dekarboksilase asam amino histidin oleh enzim dekarboksilasi histidin. Histamin merupakan salah satu indikator kemunduran mutu, terutama pada ikan-ikan famili scombroidae dan scombresocidae, seperti tuna, cakalang, tongkol, mahi-mahi, bonito, mackerel dan lain-lain (FDA, 2001; Desphande, 2002). Konsumsi ikan yang mengandung histamin melebihi ambang batas yang diijinkan (50$100 \mathrm{mg} \%$ ) dapat menyebabkan keracunan, yang ditandai dengan gatal-gatal, bercak merah pada kulit, mual, muntah, demam, dan sakit kepala.

Pada penelitian ini, kandungan bakteri pembentuk histamin pada titik ke-0 hingga 24 jam penyimpanan

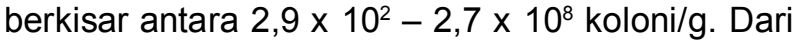
Gambar 3 dapat dilihat bahwa perlakuan perendaman dalam ekstrak bawang putih dapat menghambat pertumbuhan bakteri pembentuk histamin. Hasil penelitian juga menunjukkan bahwa semakin tinggi konsentrasi ekstrak bawang putih, kandungan bakteri pembentuk histamin semakin rendah. Dengan rendahnya jumlah bakteri pembentuk histamin,

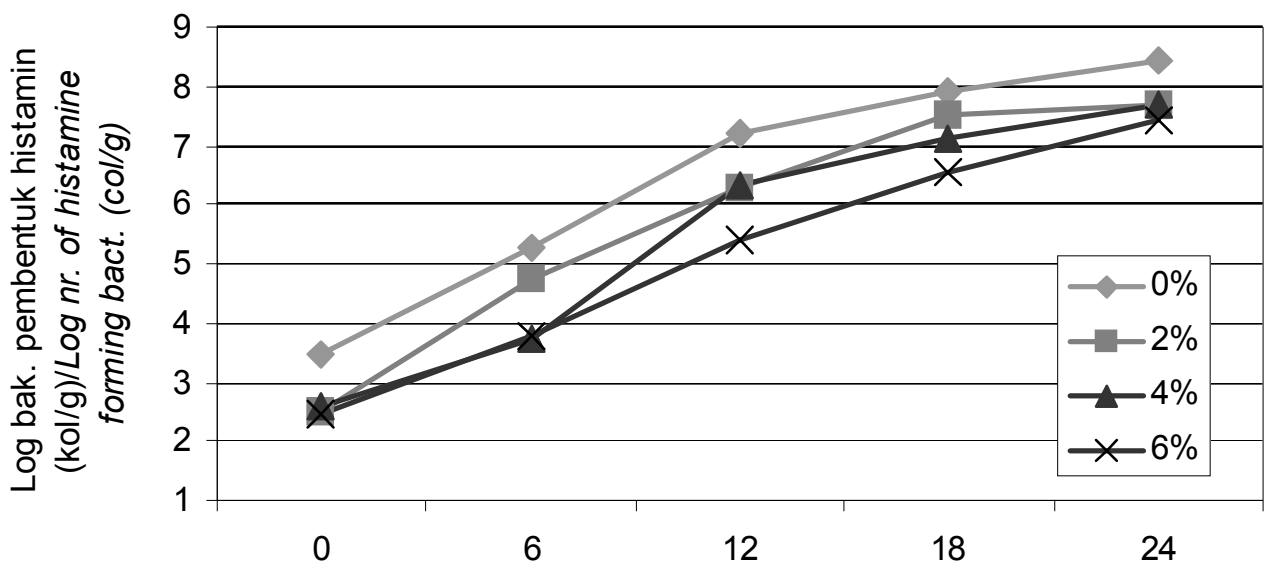

Lama penyimpanan (jam)/Storage time (hour)

Gambar 3. Jumlah bakteri pembentuk histamin ikan kembung segar hasil perlakuan perendaman ekstrak bawang putih selama penyimpanan pada suhu kamar.

Figure 3. The number of histamine forming bacteria of fresh Indian mackerel treated with garlic extract during storage at ambient temperature. 
kemungkinan besar kandungan histamin pada daging ikan juga rendah (Craven et al., 2001; Kim et al., 2002). Meskipun demikian, laju pembentukan histamin tidak selalu sebanding dengan jumlah bakteri pembentuk histamin. Hal ini karena pembentukan histamin dapat terus berlangsung secara enzimatis walaupun pertumbuhan bakteri pembentuk histamin terhambat (Fuji et al., 1994; Fletcher et al., 1998; Ariyani et al., 2004).

Selain histidin dekarboksilase, enzim histaminase juga berperan pada perombakan histidin menjadi histamin (Taylor, 1986; Middlebrooks et al., 1988; Flick et al., 2001). Enzim-enzim ini terdapat secara alami pada ikan maupun dihasilkan oleh mikroorganisme. Enterobacter, Clostridium, Hafnia, Klebsiella, Lactobacillus, Photobacterium, Proteus, Pseudomonas, dan Vibrio spp. adalah beberapa jenis bakteri penghasil enzim histidin dekarboksilase (Niven Jr et al., 1981; Eitenmiller et al., 1982; Taylor, 1986; Ababouch, 1991; Kim et al., 2002). Bakteri-bakteri ini dapat ditemukan pada bagian insang, kulit maupun saluran pencernaan ikan dan dapat tumbuh pada kisaran suhu yang luas, walaupun secara umum pertumbuhan bakteri pembentuk histamin akan terhambat pada suhu di bawah $5^{\circ} \mathrm{C}$ (Craven et al., 2001).

\section{Kadar Air}

Kadar air berperan penting dalam proses kemunduran mutu bahan pangan. Kadar air yang tinggi merupakan media yang baik bagi pertumbuhan bakteri-bakteri pembusuk, sehingga dapat mempercepat proses kerusakan suatu bahan pangan. Secara umum, tidak terdapat perbedaan kadar air yang signifikan pada perlakuan perendaman dalam larutan ekstrak bawang putih. Hal ini kemungkinan karena ikan pada seluruh perlakuan direndam selama 15 menit, baik dalam larutan ekstrak bawang putih maupun dalam air (untuk perlakuan kontrol). Kadar air ikan berkisar antara 75,93-78,21\% dengan sedikit fluktuasi (Gambar 4). Fluktuasi kadar air ini kemungkinan disebabkan oleh karena faktor lingkungan tempat penyimpanan, terutama perubahan kelembaban udara antara siang dan malam hari. Penyimpanan pada suhu kamar memungkinkan terjadinya penguapan air pada ikan yang berakibat pada penurunan kadar airnya.

\section{Uji Organoleptik}

Lendir yang terbentuk pada permukaan kulit ikan, hilangnya warna alami (diskolorisasi), dan timbulnya bau busuk merupakan tanda-tanda kemunduran mutu ikan yang disebabkan oleh aktivitas mikroorganisme. Hasil penelitian menunjukkan bahwa perlakuan perendaman dalam larutan esktrak bawang putih berpengaruh nyata terhadap nilai organoleptik ikan kembung. Perendaman dalam ekstrak bawang putih memberikan nilai organoleptik yang lebih baik dibandingkan dengan kontrol. Begitu juga dengan perlakuan konsentrasi ekstrak bawang putih, semakin tinggi konsentrasi ekstrak yang digunakan, nilai organoleptiknya semakin tinggi. Ekstrak bawang putih ternyata dapat mempertahankan kenampakan, bau serta tekstur daging ikan.

Perbedaan konsentrasi ekstrak bawang putih yang digunakan pada penelitian ini tidak berpengaruh nyata terhadap nilai organoleptik ikan kembung segar

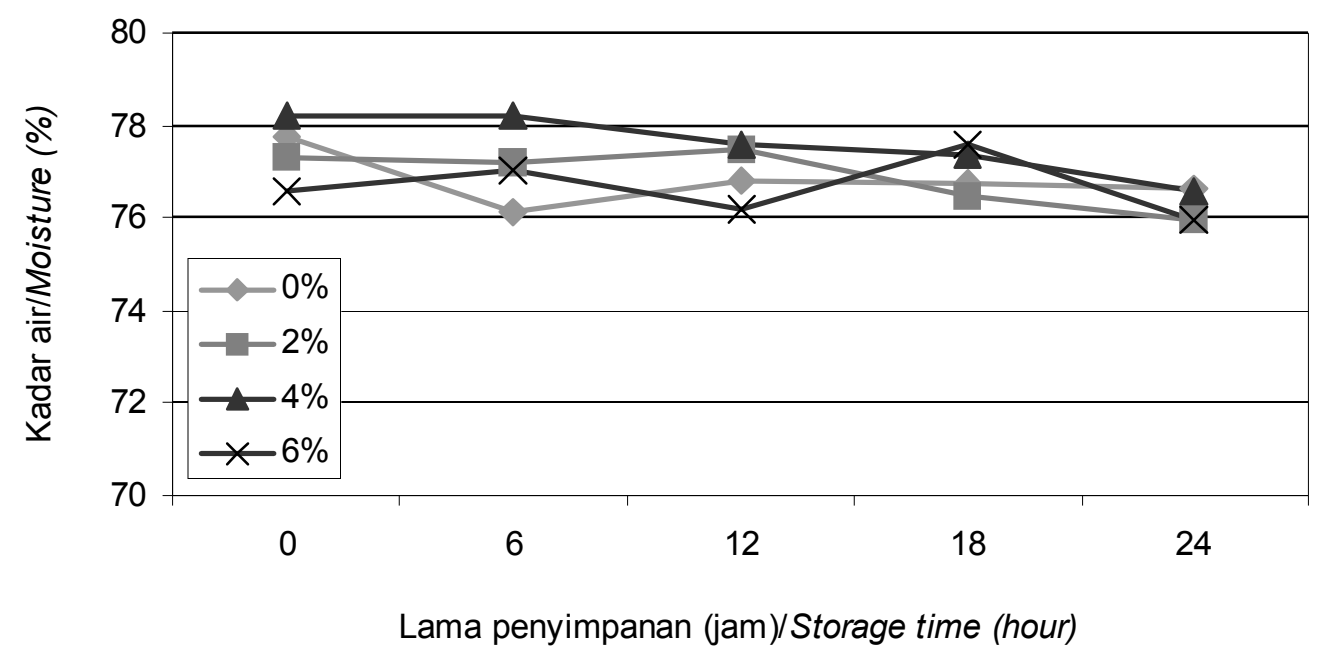

Gambar 4. Kadar air ikan kembung segar hasil perlakuan perendaman ekstrak bawang putih selama penyimpanan pada suhu kamar.

Figure 4. Moisture content of fresh Indian mackerel treated with garlic extract during storage at ambient temperature. 
selama penyimpanan pada suhu kamar. Seluruh ikan hasil perlakuan perendaman ekstrak bawang putih ditolak panelis pada jam ke-24, sedangkan perlakuan kontrol ditolak panelis pada jam ke-18. Gambar 5 menunjukkan hasil uji organoleptik ikan kembung segar, yang meliputi parameter kenampakan, mata, insang, dan lendir pada permukaan tubuh.

Uji organoleptik terhadap ikan yang dikukus (steamed) menunjukkan bahwa ikan yang direndam dalam larutan ekstrak bawang putih lebih disukai panelis dari pada ikan kontrol, terutama pada parameter kenampakan, rasa, bau, dan konsistensi (Gambar 6). Perendaman dalam ekstrak bawang putih menghasilkan ikan dengan kenampakan luar yang lebih bersih dan lebih cerah. Rasa ikan kukus yang lebih gurih dan aroma yang lebih disukai nampaknya disebabkan oleh alicin maupun senyawa turunannya (terutama diallyl sulfida) yang terdapat pada ekstrak bawang putih. Hal ini juga sesuai dengan hasil penelitian Haryati (2006). Namun demikian aroma alicin hanya terasa kuat hingga pengamatan jam ke- 6 dan berkurang pada jam pengamatan ke-12, karena senyawa alicin bersifat volatil sehingga kemungkinan besar telah menguap dan berkurang konsentrasinya setelah jam ke-6.

Konsistensi yang lebih baik pada ikan yang direndam pada larutan ekstrak bawang putih
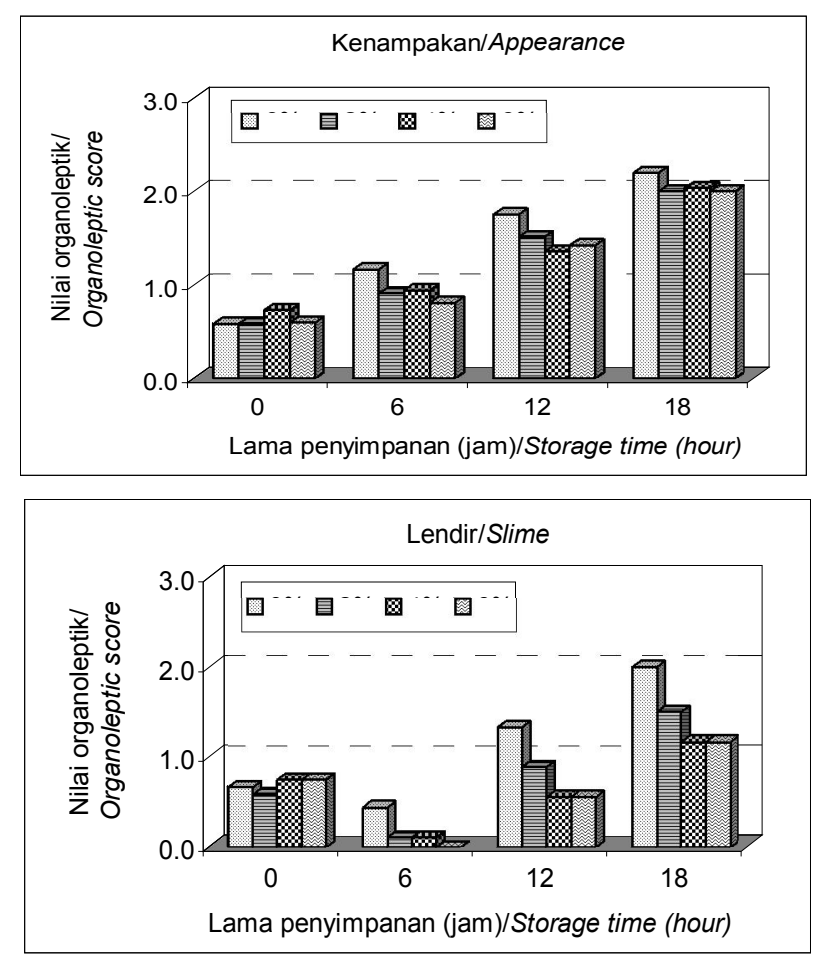

kemungkinan karena daging ikan mampu menahan air (water holding capacity) lebih baik dari pada ikan kontrol. Berdasarkan hasil uji organoleptik, kandungan TVB maupun total bakteri, ikan kembung segar yang direndam dengan ekstrak bawang putih 2-6\% masih layak untuk dikonsumsi hingga 12 jam penyimpanan pada suhu kamar, sedangkan pada ikan kontrol hanya 6 jam.

\section{KESIMPULAN DAN SARAN}

\section{Kesimpulan}

1. Perlakuan perendaman dalam ekstrak bawang putih 2-6\% dapat mempertahankan daya simpan ikan kembung segar 6 jam lebih lama dibandingkan dengan perlakuan kontrol. Hal ini karena peran senyawa antibakteri (alicin) yang terkandung pada bawang putih, sehingga menghambat pertumbuhan bakteri dan bakteri pembentuk histamin.

2. Konsentrasi ekstrak bawang putih yang berbeda berpengaruh nyata terhadap daya hambatnya pada pertumbuhan bakteri, yaitu semakin tinggi konsentrasi ekstrak bawang putih, semakin efektif daya hambatnya.

3. Perendaman dalam larutan ekstrak bawang putih juga dapat meningkatkan nilai organoleptik ikan
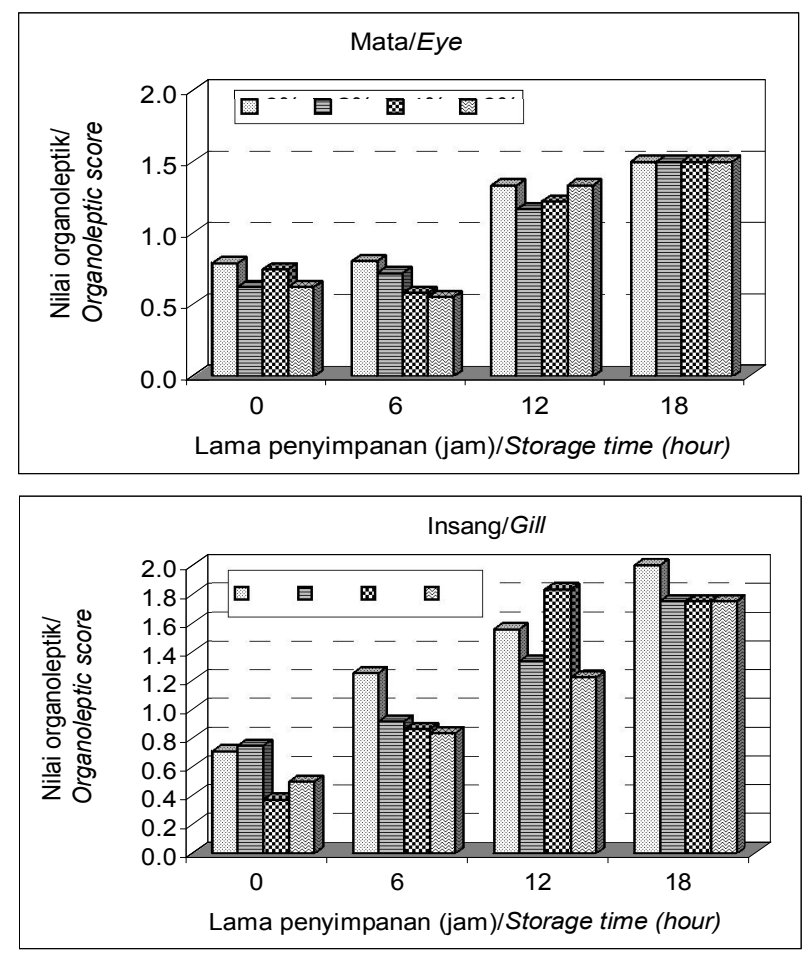

Gambar 5. Nilai organoleptik ikan kembung mentah hasil perlakuan perendaman ekstrak bawang putih selama penyimpanan pada suhu kamar.

Figure 5. Organoleptic score of fresh Indian mackerel treated with garlic extract during storage at ambient temperature. 

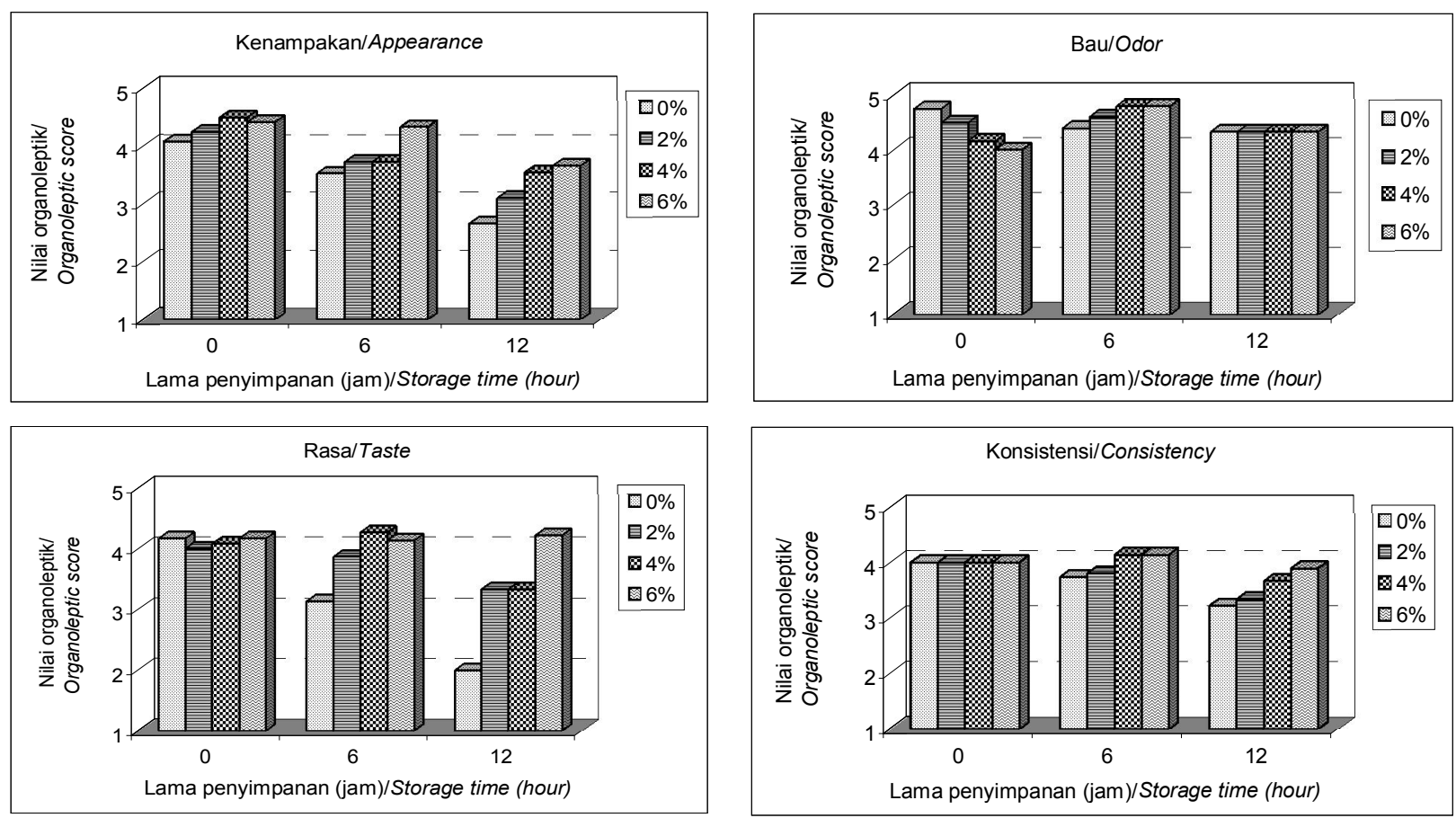

Gambar 6. Nilai organoleptik ikan kembung kukus hasil perlakuan perendaman ekstrak bawang putih selama penyimpanan pada suhu kamar.

Figure 6. Organoleptic score of steamed Indian mackerel treated with garlic extract during storage at ambient temperature.

baik kenampakan ikan segar maupun rasa dan aroma ikan setelah dikukus.

\section{Saran}

1. Perlu dicoba penggunaan ekstrak bawang putih dalam bentuk yang lain, seperti dalam bentuk tepung dan minyak untuk melihat efektifitasnya dalam menghambat pertumbuhan bakteri. Ekstrak bawang putih dalam bentuk tepung atau minyak diharapkan lebih stabil dan lebih mudah dalam penyimpanan sebelum digunakan.

2. Perlu dilakukan pengujian variasi lama perendaman ikan dalam ekstrak bawang putih untuk mencari waktu perendaman yang terbaik. Waktu perendaman yang berbeda kemungkinan berpengaruh terhadap konsentrasi bahan aktif pada ekstrak bawang putih yang terserap pada daging ikan. Sejauh ini belum ada penelitian yang mencoba lama perendaman lebih dari 15 menit.

\section{DAFTAR PUSTAKA}

Ababouch, L. 1991. Histamine food poisoning: an update. Fish Tech. News. 11: 3-5.

Andarwulan, N., Fardiaz, S., Apriyantono, A., Hariyadi, and P., Shetty, K. 1999. Mobilization of primary metabolites and phenolics during natural fermentation in seeds of Pangium edule Reinw. Procc Biochem. 35:197-204.
AOAC. 1990. Official Methods of Analysis of the Association of Official Analytical Chemist, $15^{\text {th }}$ ed. Arlington.

Ariyani, F., Yulianti, dan Martati, T. 2004. Studi perubahan kadar histamin pada pindang tongkol (Euthynnus affinis) selama penyimpanan. J. Penel. Perikanan Indonesia. 10(3): 35-46.

Branch, A.C. and Vail, A.M.A. 1985. Bringing fish inspection into the computer age. Food Technol. Aust. 37(8): 352-355.

Buckle, K.A., Edwards, R.A., Fleet, G.H., dan Wootton, M. 1987. Ilmu Pangan. (Penerjemah Purnomo, H. dan Adiono). Departemen Pendidikan dan Kebudayaan, Jakarta.

Connell, J.J. 1990. Control of Fish Quality. $3^{\text {rd }}$ ed. Fishing News Book. Oxford.

Craven, C., Hilderbrand, K., Kolbe, E., Sylvia, G., Daeschel M., Gloria B., and An, H.J. 2001. Understanding and Controlling Histamine Formation in Troll-caught Albacore Tuna. A Review and Update of Preliminary Findings from the 1994 Season. Oregon State University Sea Grant, Oregon.

Desphande, S.S. 2002. Handbook of Food Toxicology. Marcel Dekker, New York. 697 pp.

Desrosier, N.W. 1988. Teknologi Pengawetan Pangan. Alih bahasa M. Muljohardjo. $3^{\text {rd }}$ eds. Universitas Indonesia (UI) Press, Jakarta.

Eitenmiller, R.R., Orr, J.H., and Wallis, W.W. 1982. Histamine formation in fish: microbiological and biochemical condition. In Martin, R.E., Flick, G.J., Hebard, C.E., and Ward, D.R. (eds.). Chemistry and 
Biochemistry of Marine Food Products. AVI Publ. Co. Connecticut.

FDA. 2001. Fish and Fisheries Product Hazards and Controls Guidance. $3^{\text {rd }}$ ed. U.S. FDA. Center for Food Safety and Applied Nutrition, Maryland.

Feldberg, R.S., Chang, S.C., Kotik, A.N., Neuwirth, Z., Sundstrom, D.C., and Thompson, N.H. 1988. In vitro mechanism of inhibition of bacterial cell growth by allicin. Antimicrob Agents Chemother. 32: 17631768.

Fletcher, G.C., Summers, G., and Van Veghel, P.W.C. 1998. Levels of histamine and histamine producing bacteria in smoked fish from New Zealand market. J. Food. Prot. 61(8):1064-1070.

Flick, G.J., Oria, M.P., dan Douglas, L. 2001. Potential Hazard in Cold Smoked Fish: biogenic amines. J. Food Sci. 66: 1088-1099.

Fraser O.P. and Sumar S. 1998. Compositional changes and spoilage in fish (Part II) - microbiological induced deterioration. Nut. \& Food Sci. 98(6): 325329.

Fujii, T., Kurihara, K., and Okuzumi, M. 1994. Viability and histidine decarboxylase activity of halophilic histamine-forming bacteria during frozen storage. J. Food Prot. 57(7): 611-613.

Gram, L. and Huss, H.H. 1996. Microbiological spoilage of fish and fish products. Int. J. Food Microbiol. 33(1): 121-137.

Haaland, H. and Njaa, L.R. 1989. Total volatile nitrogen - a quality criterion for fish silage? Aquaculture. 79: 311-316.

Haryati, S. 2006. Optimalisasi Penggunaan Bawang Putih Sebagai Pengawet Alami Dalam Pengolahan Ikan Asin Jambal Roti. Skripsi. Sekolah Pascasarjana. Institut Pertanian Bogor.

Kim S.H., Price R.J., Morrissey, M.T., Field K.G., Wei, C.I., and An, H. 2002. Occurance of histamine-forming bacteria in albacore and histamine accumulation in muscle at ambient temperature. J. Food Sci. 67(4): 1515-1521.

Koizumi, C., Ohshima, T., and Wada, S. 1985. Preservative effect of sodium chloride in salted and dried fish products. Bull. Jpn Soc. Sci. Fish. 51: 8790.

Lugasi, A., Losada, V., Hovari, J., Lebovics, V., Jakoczi, I., and Aubourg, S. 2007. Effect of pre-soaking whole pelagic fish in a plant extract on sensory and biochemical changes during subsequent frozen storage. LWT. 40: 930-936.

Middlebrooks B.L., Toom P.M., Douglas W.L., Harrison R.E., and McDowell S. 1988. Effect of storage time and temperature on the microflora and amine development in Spanish mackerel (Scomberomorus maculatus). J. Food Sci. 53: 1024-1029.

Muchtadi, T.R. 1997. Teknologi Proses Pengolahan Pangan. Departemen Pendidikan dan Kebudayaan Direktorat Jenderal Pendidikan Tinggi, Pusat Antar Universitas Pangan dan Gizi, Institut Pertanian Bogor.

Niven, Jr. C.F., Jeffrey, M.B., and Corlett, Jr. D.A. 1981. Differential planting medium for quantitative detection of histamine-forming bacteria. Appl. \& Env. Microbiol. 41(1): 321-322.

Poerwadi dan Indriati, N. 1984. Report on Visit by RIFT Personal to Hobart. Tasmania, Australia.

SNI 01-2332.3. 2006. Metode Pengujian Mikrobiologi Produk Perikanan, Penentuan Total Plate Count. Badan Standarisasi Nasional, Jakarta. 10 pp.

SNI 01-2354.2. 2006. Cara Uji Kimia-Bagian 2: Penentuan Kadar Air pada Produk Perikanan. Badan Standarisasi Nasional, Jakarta. 10 pp.

SNI 01-2729.2. 2006: Ikan Segar-Bagian 2: Persyaratan Bahan Baku. Badan Standarisasi Nasional, Jakarta. $10 \mathrm{pp}$.

Suharti, S. 2004. Kajian Antibakteri Temulawak, Jahe dan Bawang Putih Terhadap Bakteri Salmonella typhimurium Serta Pengaruh Bawang Putih Terhadap Performan dan Respon Imun Ayam Pindang. Tesis. Sekolah Pascasarjana, Institut Pertanian Bogor.

Soetomo, S. 1987. Bertanam Bawang. BP Karya Baru, Jakarta.

Taylor, S.L. 1986. Histamine food poisoning: toxicology and clinical aspect. CRC Crit. Rev. Toxicol. 17(2): 91-128.

Wibowo, S. dan Yunizal, 1998. Penanganan Ikan Segar. Instalasi Penelitian Perikanan Laut Slipi, Badan Litbang Pertanian, Jakarta.

Zamir, R., Qasim, R., and Khan M.A. 1999. Physicochemical changes in tissue of edible mussels Perna viridis at refigerator temperature. Pakistan J. Biologic. Sci. 2(1): 151-156. 